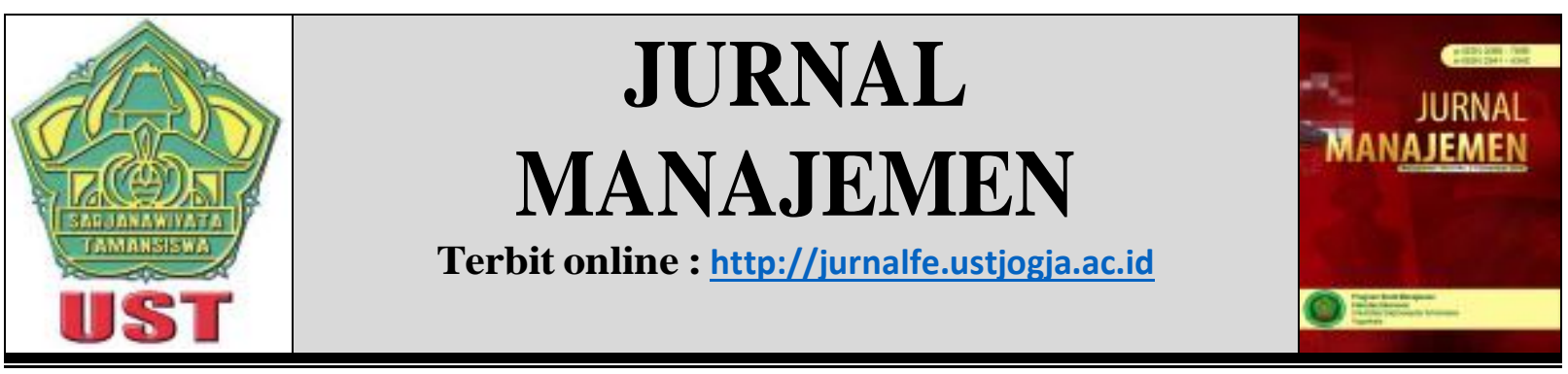

\title{
PENGARUH ELEMEN-ELEMEN KEPEMIMPINAN TRANSFORMASIONAL TERHADAP KINERJA MENGAJAR GURU MELALUI KOMITMEN AFEKTIF PADA PEKERJAAN SEBAGAI VARIABEL INTERVENING
}

\section{Eka Destriyanto Pristi Ayuningtyas}

\author{
Program Studi Manajemen Fakultas Ekonomi \\ Universitas Muhammadiyah Ponorogo \\ Korespondensi: ekadestry@gmail.com
}

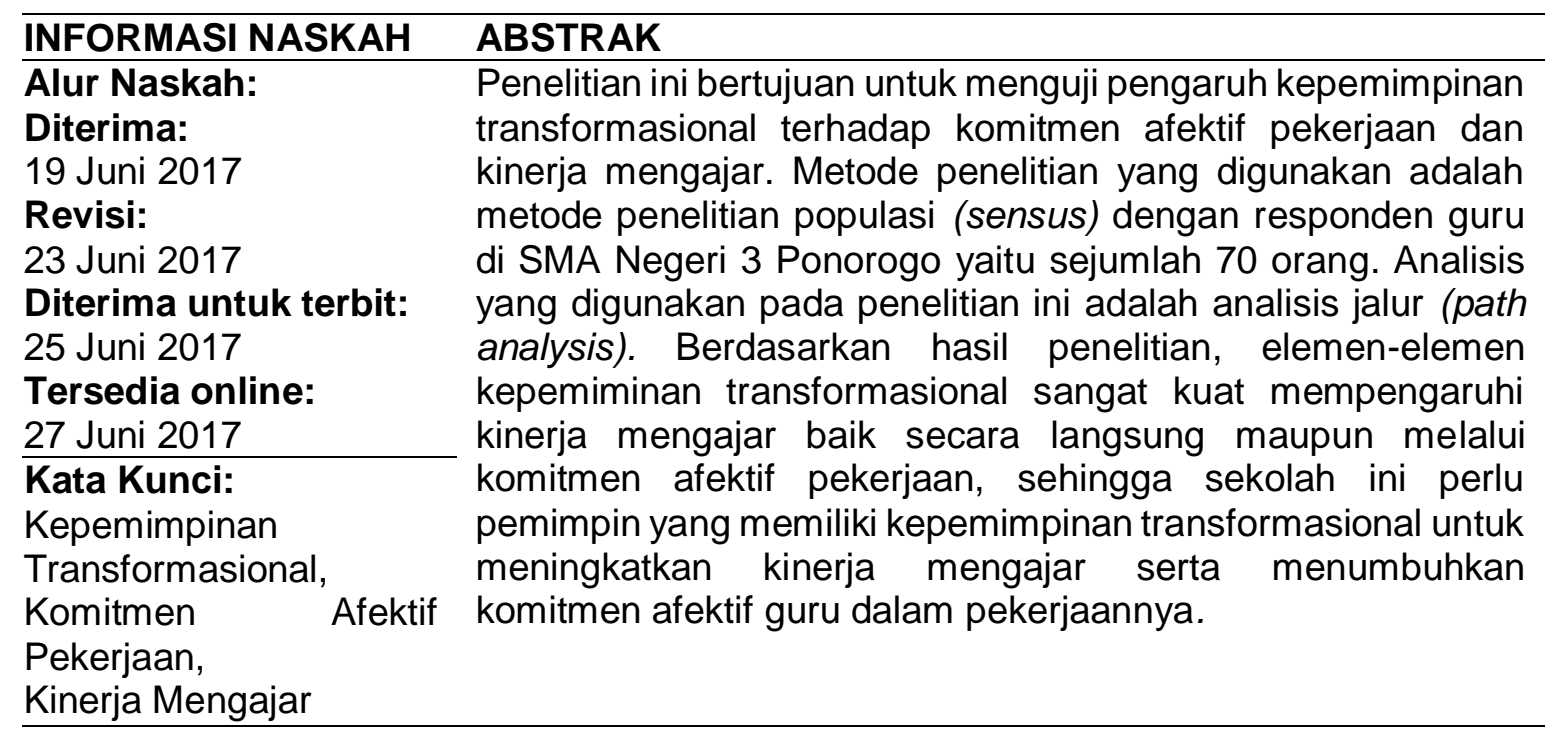

\section{PENDAHULUAN}

Pengertian kepemimpinan transformasional yaitu membuat organisasi, karyawan dan pihak-pihak yang terkait berkembang secara bersama, mengalami perubahan ke arah yang lebih luas. Pemimpin transformasional membuat karyawan melihat bahwa tujuan yang akan dicapai lebih dari sekedar kepentingan pribadinya. Kepemimpinan berkaitan dengan proses yang mempengaruhi orang sehingga mereka mencapai sasaran dalam keadaan tertentu, dimana seorang pemimpin dapat menciptakan visi dan mengembangkan kepercayaan, kesetaraan, keterbukaan dan menghargai pendapat para karyawan untuk selalu ikut terlibat dalam setiap pengambilan keputusan (take decision) dan untuk selalu berprestasi dalam organisasi.

Pimpinan dalam organisasi atau lembaga pendidikan di sekolah adalah Kepala Sekolah. Kepala Sekolah harus bertindak sebagai manajer dan pemimpin yang efektif. Sebagai manajer yang baik, Kepala Sekolah harus mampu mengatur agar semua potensi 
sekolah dapat berfungsi secara optimal dalam mendukung tercapainya tujuan sekolah. Dilihat dari segi kepemimpinan, seorang Kepala Sekolah sebagai pemimpin perlu mengadopsi gaya Kepemimpinan transformasional (Barnett, et.al. :2000) agar semua potensi yang ada di sekolah dapat berfungs secara optimal.

Kepemimpinan transformasional dapat didefinisikan sebagai gaya kepemimpinan yang mengutamakan pemberian kesempatan dan atau mendorong semua unsur yang ada dalam sekolah untuk bekerja atas dasar sistem nilai yang luhur sehingga semua unsur yang ada di sekolah (guru, siswa, pegawai, orangtua siswa, masyarakat) bersedia, tanpa paksaan, berpartisipasi secara optimal dalam mencapai tujuan ideal sekolah.

Kepala Sekolah yang memiliki kepemimpinan transformasional memiliki kecenderungan untuk menghargai ide-ide baru, cara baru, praktik-praktik baru dalam proses belajar mengajar di sekolahnya. Akibat positifnya ialah dapat ditemukannya solusi bagi persoalan keseharian yang dihadapi Guru dalam proses belajar mengajar di kelas. Jika hal ini terjadi, berarti Guru akan mampu memecahkan sendiri persoalan yang muncul dari praktik profesionalnya, sehingga mereka dapat selalu meningkatkan profesionalismenya secara berkelanjutan. Agar proses inovasi di sekolah dapat berjalan dengan baik, Kepala Sekolah perlu dan harus bertindak sebagai pemimpin \{leader), dan bukannya bertindak sebagai boss.

Menurut Bass 1990), kepemimpinan transformasional yang terjadi biasanya adalah yang mengarah pada perubahan dinamis, tantangan, visioner, perasaan hati, nilai, motivasional, serta inovasi mampu membangkitkan motivasi kerja dan kinerja yang sangat penting artinya bagi organisasi. Kepemimpinan transformasional ini dilakukan melalui karisma, stimulus intelektual, perhatian individu, dan inspirasi yang memotivasi \{Bass, 1985) dari Kepala Sekolah sebagai pemimpin terhadap Guru sebagai karyawan. Oleh sebab itu penelitian ini memfokuskan diri pada kinerja mengajar, apakah ditentukan oleh kepemimpinan transformasional yang dilakukan Kepala Sekolah dan komitmen Guru dalam mengajar mahasiswa. Berdasarkan latar belakang masalah yang telah dikemukakan, maka penulis berkeinginan melakukan penelitian yang berjudul "Pengaruh Elemen- Elemen Kepemimpinan Transformasional terhadap Kinerja Mengajar Guru melalui Komitmen Afektif pada Pekerjaan sebagai Variabel Intervening pada Guru.

\section{KAJIAN PUSTAKA DAN HIPOTESIS Kepemimpinan}

Kepemimpinan transformasional menurut Burns \{1978:18) merupakan proses dimana pemimpin menaikkan moral dan motivasi bawahan ke tingkat yang lebih tinggi. Bass \{1990), mengemukakan ada tiga cara seorang pemimpin transformasional memotivasi karyawannya, yaitu dengan:

1. Mendorong karyawan untuk lebih menyadari arti penting hasil usaha.

2. Mendorong karyawan untuk mendahulukan kepentingan kelompok.

3. Meningkatkan kebutuhan karyawan yang lebih tinggi seperti harga diri dan aktualisasi diri.

Komponen-komponen perilaku kepemimpinan transformasional telah diidentifikasikan melalui berbagai macam cara, termasuk analisis faktor, observasi, interview dan deskripsi dari pemimpin ideal menurut para karyawan. Menurut Bass \{1985) yang didukung oleh Yukl (1998:297) mengemukakan empat karakteristik kepemimpinan transformasional, yaitu:

1. Karisma (Charisma).

2. Stimulasi Intelektual (Intellectual Stimulation).

3. Perhatian Individu (Individualized Consideration).

4. Inspirasi yang Memotivasi (Inspirational Motivation). 


\section{Komitmen Pekerjaan}

Allen dan Meyer (1990) yang mengklasifikasikan komitmen pekerjaan dalam tiga dimensi, yaitu: komitmen afektif pekerjaan (affective occupational commitment), komitmen kontinuans pekerjaan (continuance occupational commitment), dan komitmen normatif pekerjaan (normative occupational commitment). Penelitian ini akan menggunakan teori komitmen afektif pekerjaan, dimana karyawan yang memiliki komitmen ini cenderung tetap mempertahankan pekerjaannya karena memang menginginkannya. Hal ini sesuai dengan kepemimpinan transformasional dimana pemimpin memberikan arahan dan motivasi kepada karyawan tanpa adanya paksaan, aturan, sanksi maupun tuntutan kewajiban.

\section{Kinerja}

Manullang (1998) yang dimaksud dengan kinerja adalah suatu keadaan yang menunjukkan banyaknya pekerjaan yang harus dilakukan atau dihasilkan seorang individu atau sekelompok kerja ssuai dengan job discription mereka masing-masing.

Pemikiran Aleamoni dan hasil studi yang dilakukan Peterson dan Kauchak tersebut, maka penelitian ini akan menilai kinerja guru dari perspektif mahasiswa. Evaluasi kinerja oleh mahasiswa ini didesain dan diadministrasikan sesuai dengan kaidah-kaidah dan prinsipprinsip evaluasi, sehingga data yang dihasilkan akan dapat dipertanggungjawabkan dan dapat dimanfaatkan untuk kepentingan perbaikan mutu dan efektivitas pembelajaran mahasiswa.

Penelitian ini akan mengevaluasi kinerja dari perspektif mahasiswa, sehingga digunakan variabel kinerja mengajar yang diukur dari dimensi sikap, kemampuan dan keakraban guru. Hal ini dilakukan karena yang mengetahui kegiatan guru dalam mengajar sehari-hari adalah mahasiswa, hal ini seperti yang diungkapkan Aleamoni (1981).

\section{Hubungan Kepemimpinan Transformasional dengan Komitmen Afektif Pekerjaan}

Kepemimpinan transformasional menentukan tingkat komitmen seseorang pada pekerjaan. Kepemimpinan dalam hal ini yang dilakukan Kepala Sekolah, jika pemimpin itu memiliki komitmen untuk mengembangkan karyawan dan bukan sekedar menyuruh maka akan menumbuhkan komitmen karyawan dalam hal ini komitmen guru terhadap pekerjaan. Pemimpin dalam kepemimpinan transformasional menerapkan hubungan harmonis antara seorang pemimpin dengan seorang karyawan, adanya saling percaya, kekeluargaan dan penghargaan terhadap gagasan karyawan.

Karyawan umumnya akan meningkatan komitmen pada pekerjaan apabila mereka menganggap pemimpin mampu menghargai kontribusi dan memperhatikan masalah kesejahteraan mereka. Karyawan merasa hasil yang didapat sebanding dengan apa yang diharapkannya, dan merasa telah diperlakukan adil. Hubungan ditunjukkan sampai sejauh mana karyawan merasa dihargai dan dipercayai oleh pemimpin. Perhatian dan totalitas yang diberikan pemimpin transformasional tidak akan berarti tanpa adanya komitmen bersama dari masing-masing pribadi karyawan. Karyawan mempunyai komitmen tinggi akan memiliki keinginan yang kuat untuk tetap mempertahankan pekerjaannya agar dapat terus memberikan sumbangan bagi pencapaian tujuan yang mereka yakini. Individu yang mempunyai komitmen tinggi akan sepenuhnya melibatkan diri pada pekerjaan mereka tanpa adanya paksaan namun karena mereka menginginkannya. Hal ini sesuai dengan kepemimpinan transformasional dimana pemimpin memberikan arahan dan motivasi kepada karyawan tanpa adanya paksaan, aturan, sanksi maupun kewajiban. Seseorang dengan komitmen afektif pekerjaan yang kuat cenderung bertahan pada pekerjaan karena memang dia menyukai dan menginginkan pekerjaannya. 


\section{Hubungan antara Kepemimpinan Transformasional dengan Kinerja Mengajar Guru}

Banyak faktor yang mempengaruhi tinggi rendahnya kinerja seseorang. Kinerja dapat diartikan sebagai hasil kerja yang dicapai seseorang sesuai dengan ketentuan yang berlaku dalam suatu kelompok atau organisasi kerja tertentu. Kinerja merupakan suatu pencapaian persyaratan-persyaratan pekerjaan tertentu yang akhirnya secara langsung dapat tercermin dari output yang dihasilkan baik jumlah maupun kualitasnya. Kinerja karyawan berbeda antara karyawan satu dengan karyawan yang lain. Perbedaan ini disebabkan oleh adanya dua faktor, yaitu faktor individu dan faktor situasi. Faktor individu tersebut antara lain kondisi fisik, kemampuan, motivasi dan faktor-faktor individual lainnya. Faktor situasi yang mempengaruhi antara lain kondisi kerja yang menyenangkan, sarana yang menunjang, adanya pengakuan atas kinerja yang baik, pemimpin yang mengerti akan kebutuhan karyawan serta sistem kerja yang mendukung. Beberapa pendapat yang telah dikemukakan dapat diketahui peran pemimpin sangatlah penting dalam usaha meningkatkan kinerja karyawan yang berada di bawah kekuasaan dan wewenangnya. Perilaku pemimpin dalam melaksanakan tugasnya merupakan panutan bagi bawahannya.

\section{Hubungan antara Komitmen Afektif Pekerjaan dengan Kinerja Mengajar Guru}

Komitmen karyawan pada pekerjaan atau komitmen occupational merupakan salah satu sikap karyawan yang penting dalam melakukan pekerjaan. Komitmen occupational merupakan suatu kondisi yang dirasakan oleh karyawan sehingga dapat menimbulkan perilaku potitif yang kuat terhadap pekerjaannya. Komitmen afektif pekerjaan merupakan salah satu dari tiga komponen komponen occupational dimana karyawan bertahan pada suatu pekerjaan karena mereka menyukai dan menginginkan pekerjaan tersebut.

Komitmen karyawan terhadap pekerjaan yang didasari keinginan individu dan tanpa adanya paksaan dari luar ini diyakini mampu mempengaruhi kinerja karyawan dalam menjalankan tugasnya. Tingginya komitmen afektif terhadap pekerjaan yang dimiliki karyawan yang dalam hal ini komitmen guru dalam bekerja akan mengakibatkan kinerja mengajar menjadi lebih baik.

Kinerja mengajar seorang guru dapat ditingkatkan jika guru tersebut memiliki komitmen terhadap pekerjaannya. Apalagi komitmen tersebut berasal dari keinginan individu yang bersangkutan bukan karena adanya tuntutan kewajiban ataupun tekanan pihak lain. Komitmen ini akan membawa semangat dalam bekerja sehingga kinerja mengajar menjadi baik.

\section{HIPOTESIS}

$\mathrm{H} 1=$ Variabel karisma berpengaruh signifikan terhadap kinerja mengajar guru.

$\mathrm{H} 2=$ Variabel stimulasi intelektual berpengaruh signifikan terhadap kinerja mengajar guru.

$\mathrm{H} 3$ = Variabel perhatian individu berpengaruh signifikan terhadap kinerja mengajar guru.

$\mathrm{H} 4=$ Variabel inspirasi yang memotivasi berpengaruh signifikan terhadap kinerja mengajar guru.

H5 = Variabel karisma berpengaruh signifikan terhadap kinerja mengajar melalui variabel intervening komitmen afektif pekerjaan guru.

H6 = Variabel stimulasi intelektual berpengaruh signifikan terhadap kinerja mengajar melalui variabel intervening komitmen afektif pekerjaan guru.

H7 = Variabel perhatian individu berpengaruh signifikan terhadap kinerja mengajar melalui variabel intervening komitmen afektif pekerjaan guru.

$\mathrm{H} 8=$ Variabel inspiras yang memotivasi berpengaruh signifikan terhadap kinerja mengajar melalui variabel intervening komitmen afektif pekerjaan guru 


\section{METODE PENELITIAN}

Penelitian ini menggunakan metode penelitian kuantitatif. Populasi pada penelitian adalah guru di SMA Negeri 3 Ponorogo berjumlah 70 orang. Penelitian ini penulis mengambil semua objek sebagai sampel, karena jumlah objek kurang dari 100 sehingga penelitian ini merupakan penelitian populasi. Data yang digunakan dalam penelitian ini adalah data primer dan data sekunder. Data Primer merupakan data yang diperoleh langsung dari obyek penelitian melalui kuisioner. Data Sekunder berupa data atau catatan yang bersifat menunjang dan untuk melengkapi data primer. Penelitian ini menggunakan analisis jalur (path analysis) untuk menguji dan menjelaskan hubungan kausalitas antara satu atau beberapa variabel.

\section{HASIL DAN PEMBAHASAN}

Analisa deskriptif dan uji hipotesis telah dilakukan, berikut ini disajikan interpretasi MODEL KONSEP hasil

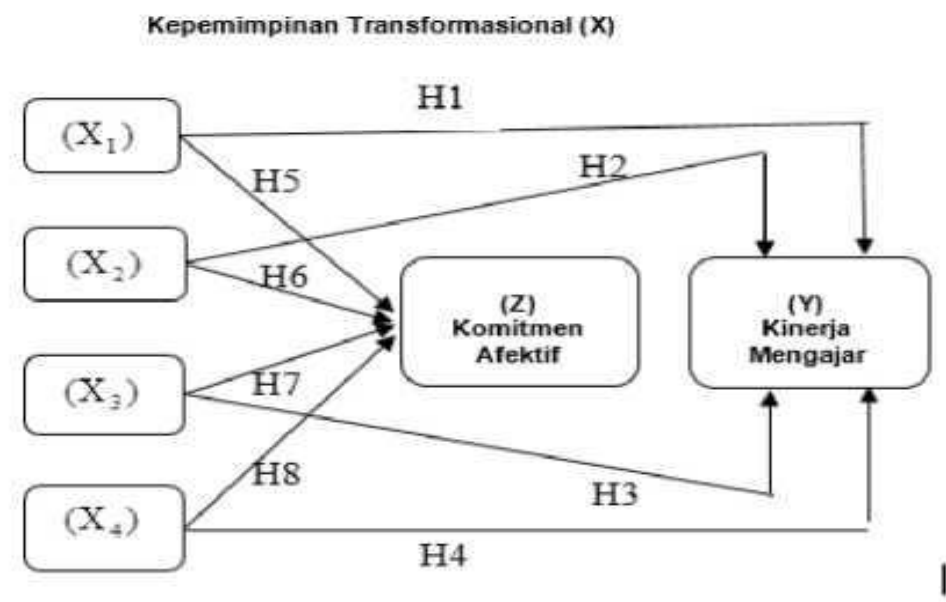

penelitian tersebut dengan mengkaitkan antara data dan teori yang mendasarinya. Temuan menarik dari hasil studi ini adalah terbuktinya hipotesis yang diajukan tentang hubungan kausalitas antara elemen-elemen kepemimpinen transformasional, komitmen pekerjaan afektif, dan kinerja mengajar di SMA Negeri 3 Ponorogo. Berdasarkan kajian teoritis dan hasil penelitian terdahulu, diketahui bahwa untuk meningkatkan kinerja diperlukan karyawan yang memiliki komitmen kuat pada pekerjaan yang secara tidak langsung akan berdampak pula pada organisasi. Bentuk komitmen karyawan yang mendasar adalah terbentuknya keterikatan psikologis atau emosional antara karyawan dengan pekerjaan tanpa mempedulikan apapun jenis pekerjaan maupun organisasinya. Komitmen dalam bentuk keterikatan psikologis tersebut, diyakini memiliki kekuatan untuk mendukung pencapaian tujuan, bukan karena semata-mata dorongan memperoleh imbalan maupun perasaan balas budi akan tetapi karena adanya keinginan untuk tetap pada pekerjaannya. Komitmen karyawan menjadi hal yang penting karena komitmen karyawan berdampak positif terhadap sikap dan perilaku karyawan untuk mendukung pencapaian tujuan organisasi. Komitmen dinilai sebagai mediator penting bagi penguatan motivasi kerja pegawai untuk meningkatkan kinerja (Davis dan Newstrom, 2001).

Salah satu upaya untuk membangun komitmen afektif pekerjaan dalam hal ini guru adalah adanya perilaku pemimpin yang bersifat transformasional yaitu pemimpin yang memiliki karisma, stimulus intelektual, perhatian individu dan inspirasi yang memotivasi. 
Pemimpin dalam penelitian ini adalah Kepala Sekolah. Secara teoritis, guru yang mendapatkan karisma, stimulus intelektual, perhatian individu dan inspirasi yang memotivasi dari Kepala Sekolah sebagai pemimpin akan membangkitkan sikap positif dalam melakukan pekerjaan antara lain dalam bentuk komitmen terhadap pekerjaan.

Hasil uji statistik diketahui bahwa karisma, stimulus intelektual, perhatian individu dan inspirasi yang memotivasi secara langsung berpengaruh positif dan signifikan terhadap komitmen afektif pekerjaan. Hasil ini jelas mengindikasikan bahwa kepemimpinan transformasional yang dilakukan Kepala Sekolah baik berupa karisma (sikap yang menimbulkan keteladanan), stimulus intelektual (sikap yang memacu dan mendorong untuk berkembang), perhatian individu (sikap yang memperlakukan guru sebagai individu) dan inspirasi yang memotivasi (sikap yang memberikan motivasi guru tentang kondisi masa depan kampus secara optimis), kepemimpinan yang ditunjukkan Kepala Sekolah kepada guru akan memperkuat komitmen afektif guru dalam melakukan pekerjaan. Hasil uji statistik pengaruh elemen kepemimpinan transformasional terhadap komitmen afektif pekerjaan juga diperkuat oleh hasil statistik deskriptif. Hasil uji statistik deskriptif terhadap variabel karisma, stimulus intelektual, perhatian individu dan inspirasi yang memotivasi dapat dikategorikan tinggi, yaitu masing- masing 4,08; 3,85; 3,79; dan 4,11. Demikian pula nilai total rata-rata komitmen afektif pekerjaan juga tinggi yaitu 3,96, sehingga dapat diinterpretasi bahwa pada konteks SMA Negeri 3 Ponorogo elemen kepemimpinan transformasional dari Kepala Sekolah yang tinggi menurut guru sebagai karyawan akan menghasilkan komitmen afektif yang tinggi pula terhadap pekerjaannya. Selanjutnya hasil statistik terhadap variabel kinerja mengajar juga menunjukkan nilai total rata-rata sebesar 3,96 yang dapat dikategorikan tinggi, dalam arti bahwa pada konteks SMA Negeri 3 Ponorogo elemen kepemimpinan transformasional dari Kepala Sekolah yang tinggi menurut guru sebagai karyawan akan menghasilkan kinerja mengajar yang baik.

Telaah lebih lanjut dari hasil uji statistik menunjukkan bahwa elemen kepemimpinan transformasional yang terdiri dari karisma, stimulus intelektual, perhatian individu dan inspirasi yang memotivasi berpengaruh signifikan secara langsung terhadap kinerja mengajar yaitu masing-masing sebesar 0,$259 ; 0,265 ; 0,293$; dan 0,435 , mempunyai nilai standar koefisien lebih besar jika dibandingkan dengan pengaruh tidak langsung secara signifikan melalui komitmen afektif pekerjaan yaitu masing-masing sebesar 0,$136 ; 0,107$; 0,208 ; dan 0,189. Hal ini memberikan implikasi bahwa meskipun tanpa adanya komitmen afektif terhadap pekerjaan, kinerja mengajar guru sudah baik asalkan pemimpin mempunyai sikap transformasional. Namun demikian, komitmen afektif pekerjaan juga berpengaruh signifikan terhadap kinerja mengajar. Sehingga dapat disimpulkan bahwa elemen kepemimpinan transformasional yang terdiri dari karisma, stimulus intelektual, perhatian individu dan inspirasi yang memotivasi mempunyai pengaruh langsung lebih kuat terhadap kinerja mengajar dibandingkan melalui variabel intervening komitmen afektif pekerjaan.

Hasil penelitian ini secara umum juga mendukung hasil penelitian sebelumnya, antara lain oleh Parsaulian (2007) dan Haryadi (2005). Hasil penelitian oleh Parsaulian menemukan korelasi positif dan signifikan antara kepemimpinan transformasional dengan komitmen karyawan. Hasil ini juga mendukung penelitian Haryadi yang menyimpulkan selain kepemimpinan transformasional ada variabel lain yang ikut mempengaruhi kinerja karyawan yaitu komitmen terhadap pekerjaan. Namun dalam penelitian ini lebih dijelaskan bahwa pengaruh secara langsung antara elemen-elemen kepemimpinan transformasional terhadap kinerja lebih kuat dibandingkan dengan pengaruh tidak langsung yaitu melalui komitmen afektif pekerjaan. Kepala Sekolah sebagai pemimpin yang memiliki karisma dan keteladanan, selalu memberikan dorongan untuk berkembang, memperlakukan guru sebagai individu serta selalu memberikan motivasi tentang kondisi masa depan kampus secara optimis maka akan menimbulkan kinerja mengajar yang baik. Setiap tindakan yang akan 
dilakukan Kepala Sekolah selalu dikomunikasikan dengan guru, selalu diadakan musyawarah dalam setiap pengambilan keputusan, sehingga keputusan tidak hanya dari atasan namun ada umpan balik dari bawahan. Dengan demikian guru sebagai bawahan merasa dihargai dan ikut andil dalam setiap keputusan yang diambil Kepala Sekolah sebagai pemimpin, sehingga guru lebih semangat dalam menjalankan tugasnya. Oleh karena itu, kepemimpinan transformasional begitu kuat mempengaruhi kinerja guru dalam mengajar.

Hipotesis bagian kedua dalam penelitian ini juga terbukti, yaitu menyatakan elemenelemen kepemimpinan transformasional berpengaruh terhadap kinerja mengajar melalui komitmen afektif pekerjaan, namun tidak sekuat pengaruh terhadap kinerja mengajar secara langsung. Hal ini berarti bahwa jika Kepala Sekolah menerapkan gaya kepemimpinan selain kepemimpinan transformasional, maka kinerja mengajar guru tetap baik meskipun mengalami penurunan. Hal ini dikarenakan guru telah memiliki komitmen afektif terhadap pekerjaan. Guru tetap bertahan dalam pekerjaannya karena memang menyukai dan menginginkan pekerjaan tersebut, dengan demikian kinerja mengajar tetap baik. Hasil ini diperkuat dengan uji statistik pada pengaruh langsung antara komitmen afektif pekerjaan terhadap kinerja mengajar sebesar 0,351 .

Hasil penelitian juga menunjukkan bahwa variabel inspirasi yang memotivasi merupakan variabel yang paling kuat mempengaruhi kinerja mengajar secara langsung, yaitu sebesar 0,435. Hasil ini memperkuat pendapat Yukl (1998) yaitu seorang pemimpin yang inspirational mampu menciptakan kepercayaan diri pada karyawan. Kepercayaan atau keyakinan diri yang besar terhadap apa yang dikerjakan akan menimbulkan usaha yang melebihi usaha biasanya sehingga berdampak pada peningkatan kinerja.

\section{PENUTUP}

Berdasarkan hasil analisis data penelitian dan pembahasan dapat dirumuskan simpulan penelitian sebagai berikut:

1. Berdasarkan analisis statistik deskriptif atas jawaban responden, secara umum guru SMA Negeri 3 Ponorogo menilai bahwa Kepala Sekolah menerapkan kepemimpinan transformasional melalui karisma, stimulus intelektual, perhatian individu, dan inspirasi yang memotivasi. Hasil statistik deskriptif juga menunjukkan guru SMA Negeri 3 Ponorogo memiliki komitmen afektif pada pekerjaan dan kinerja mengajar yang tinggi.

2. Berdasarkan hasil uji analisis jalur, disimpulkan bahwa elemen- elemen kepemimpinan transformasional yang terdiri dari karisma, stimulus intelektual, perhatian individu, inspirasi yang memotivasi berpengaruh signifikan terhadap kinerja mengajar baik secara langsung maupun melalui variabel intervening komitmen afektif pekerjaan terbukti

3. Berdasarkan uji analisis jalur dapat disimpulkan bahwa karisma, stimulus intelektual, perhatian individu, dan inspirasi yang memotivasi memiliki pengaruh langsung lebih besar terhadap kinerja mengajar, dibandingkan pengaruh tidak langsung yaitu melalui komitmen afektif pekerjaan.

4. Berdasarkan nilai koefisien determinasi dapat disimpulkan bahwa secara bersama-sama elemen-elemen kepemimpinan transformasional berpengaruh terhadap kinerja mengajar sebesar 94,8\%, sedangkan berpengaruh terhadap komitmen afektif pekerjaan sebesar $88,3 \%$.

5. Berdasarkan nilai koefisien jalur, disimpulkan bahwa secara langsung variabel inspirasi yang memotivasi mempunyai pengaruh dominan terhadap kinerja mengajar sebesar 0,435 . 


\section{DAFTAR PUSTAKA}

Aleamoni, Lawrence M. 1981. Student Ratings of Instruction: Handbook of Teacher Evaluation. Boston: Academic Publishers.

Allen, N.J. and J.P. Mayer. 1990. The Measurement and Antecedents of Affective, Continuance, and Normative Commitment to the Organization. Journal of Occupational Psychology. No. 91: 1-18.

Barnett, Kerry, et al. 2000. Leadership Behaviour of Secondary School Principals, Teacher

Outcomes and Scgool Culture. Paper Presented at the Australian Association for Research in Education Annual Conference. University of New South Wales.

Bass, Bernard M. 1985. Leadership and Performance Beyond Expectations. New York: The Free Press.

- - 1990. Bass and Stogdill's Hand Book of Leadership. New York: The Free Press.

Bass, Bernard M. et al. 2003. Predicting Unit Performance by Assessing Transformational and Transactional Leadership. Journal of Applied Psychology. (Vol. 12): 207218.

Burns, J.M. 1978. Leadership. New York: Harper and Row.

Davis, Keith and John W. Newstrom. 2001. Perilaku dalam Organisasi Alih Bahasa: Agus Dharma. Jakarta: Erlangga

Ferdinand, Augusty. 2002. Structural Equation Modeling Dalam Penelitian Manajemen: Aplikasi Model-model Rumit Dalam Penelitian Untuk Tesis Magister dan Disertasi Doktor. Semarang: $\quad$ Universitas Diponegoro.

Malhotra, Naresh K. 2002. Marketing Research. New York: Prentice-Hall, Inc.

Manullang. 1998. Manajemen Sumber Daya Manusia. Jakarta: Ghalia Indonesia. 